\author{
Jurnal Penelitian Pendidikan Fisika, Vol. 5 No. 1 Januari 2020, 1-8 \\ Available Online at http://ojs.uho.ac.id/index.php/JIPFI \\ p-ISSN: 2502-3861 | e-ISSN: 2715-551X
}

\title{
Penerapan Model Discovery Learning Terhadap Keaktifan dan Hasil Belajar Siswa Kelas X MIPA SMAN 1 Piyungan Yogyakarta
}

\author{
Maria Yosephien Retna Tinon Kawuri ${ }^{1)}$, Suritno Fayanto ${ }^{2)}$ \\ ${ }^{1}$ Guru Fisika, SMAN 1 Piyungan, Jl. Karang Gayam Piyungan, Yogyakarta, Indonesia. \\ ${ }^{2}$ Magister Pendidikan Fisika, Universitas Ahmad Dahlan, Jl. Pramuka No 42, Yogyakarta, Indonesia. \\ Email: myretna@gmail.com
}

\begin{abstract}
Activity learning is student activities during learning. Active learning is learning that supply and provides an opportunity for students to learn on their own or their activities that have an impact on learning outcomes. The purpose of this study was to describe the activity and student learning outcomes by applying the model of discovery learning. The research sample is Class X MIPA Public High School 1 Piyungan. This type of research is classroom action research consisted of two cycles of cycle 1 and cycle 2. Data collection techniques are using observation sheets and test sheets, As for the data analysis using descriptive analysis. The results of the analysis that studied physics Increased activity class $X$ MIPA Public High School 1 Piyungan with discovery learningon the measurement of physical quantities in the academic year 2019/2020 of the first cycle in the first meeting and the second meeting was increased from $88.5 \%$ to $93.0 \%$, i.e. $4.50 \%$. In the second cycle increased from $92.1 \%$ to $97.0 \%$ there was an increase of 4.90. Improved physics learning outcomes of students of class X MIPA Public High School 1 Piyungan with discovery learning $(D L)$ on the material for measuring physical quantities in the academic year 2019/2020 in cycle I to cycle II from $61 \%$ to $77.8 \%$ experiencing an increase of $16.8 \%$. Improved learning outcomes show that the application of discovery learningcan be fun and make students interested and interested in learning.
\end{abstract}

Keyword: Discovery learning; Activity; Learning outcomes

\begin{abstract}
Abstrak: Aktivitas belajar merupakan kegiatan yang dilakukan siswa saat pembelajaran. Suatu pembelajaran yang efektif adalah pembelajaran yang menyediakan dan memberi kesempatan kepada siswa untuk belajar sendiri atau aktivitas sendiri sehingga berampak terhadap hasil belajar. Tujuan penelitian ini adalah untuk mendeskripsikan keaktifan dan hasil belajar siswa dengan menerepakan model pembelajaran discovery learning. Sampel penelitian yaitu Kelas X MIPA SMAN 1 Piyungan. Jenis penelitian ini adalah penelitian tindakan kelas yang terdiri dari dua siklus yaitu siklus 1 dan siklus 2. Teknik pengumpulan data yaitu menggunakan lembar observasi dan lembat tes. Sedangkan untuk analasi data menggunakan analisisi deskriptif. Hasil analisis diperoleh bahwa Peningkatan aktivitas belajar fisika siswa kelas X MIPA SMA Negeri 1 Piyungan dengan discovery learning pada pengukuran besaran fisis tahun pelajaran 2019/2020 dari siklus I pada pertemuan pertama dan pertemuan kedua mengalami peningkatan dari $88,5 \%$ menjadi $93,0 \%$ yaitu $4,50 \%$. Pada siklus II mengalami peningkatan dari $92,1 \%$ menjadi $97,0 \%$ ada peningkatan 4,90. Peningkatan hasil belajar fisika siswa kelas X MIPA SMA Negeri 1 Piyungan dengan discovery learning(DL) pada materi pengukuran besaran fisis tahun pelajaran 2019/2020 pada siklus I ke siklus IIdari $61 \%$ menjadi 77,8\% mengalami kenaikan 16,8\%. Adanya peningkatan hasil belajar menunjukkan bahwa DL yang dilaksanakan dapat menyenangkan dan membuat siswa berminat dan tertarik dalam pembelajaran tersebut.
\end{abstract}

Kata Kunci: Discovery learning; Keaktifan; Hasil belajar

\section{PENDAHULUAN}

Kurikulum 2013 menerapkan pendekatan pembelajaran scientific approach siswa dituntut untuk lebih aktif dan kritis dalam pembejaran dikelas (Kawuri et al. 2019). Kenyataan di lapangan terutama pembelajaran fisika perlu menggunakan pendekatan yang lebih berkaitan dengan masalah serta dikaitakan 
dengan kejadian sehari-hari (Sukariasih et al. 2019). Hal ini dimaksudkan agar pemahaman fisika siswa lebih tertanam di otak dan tidak menimbulkan salah konsep akan materi yang sedang dipelajari. Menurut Wina (2010) mengatakan bahwa pembelajaran di sekolah terlalu menjejali otak siswa dengan berbagi bahan ajar yang bersifat hafalan tetapi kurang mengarahkan siswa untuk mengembangkan dan membangun karakter serta kemampuan siswa. Penumpukan konsep dan informasi oleh siswa kurang bermanfaat karena materi hanya dikomunikasikan oleh guru satu arah saja. Pemahaman konsep dalam belajar sangat penting hal ini akan mempengaruhi sikap, keputusan dan cara-cara memecahkan masalah, maka belajar bermakna sangat penting (Trianto, 2009).

Melihat kenyataan yang ada di SMAN 1 Piyungan Bantul masih banyak siswa yang kurang memahami akan materi yang sedang dipelajari, demikian pula masih ada guru yang saat pembelajaran kurang bervariasi dalam menerapkan model pembelajaran. Padahal menurut tuntutan kurikulum-13 guru hendaknya menggunakan model pembelajaran yang bervariatif disesuaikan dengan materi yang dipelajari. Model pembelajaran menurut kurikulum-13 antara lain discovery learning, problem based learning, project based learning, inquiry based learning sesuai dengan pendekatan saintifik yaitu 5M (mengamati, menanya, mengumpulkan data, mengasosiasi, mengomunikasikan) (Sofyan \& Komariah, 2016). Saat pembelajaran berlangsung masih banyak siswa kurang berani bertanya apabila ada materi yang kurang paham, siswa kurang berani mengemukakan pendapat, siswa masih ada yang bercanda dan ramai saat pembelajaran, siswa kurang merespon tugas yang diberikan guru. Siswa cenderung asyik dengan kesibukan sendiri yang mengganggu siswa lain saat pembelajaran berlangsung, yang akhirnya hasil belajar siswa kurang maksimal (Fayanto et al. 2019). Demikian pula saat ulangan harian masih ditemukan siswa yang kurang percaya diri akan kemampuan yang dimiliki karena masih ada siswa yang bertanya teman lain saat ulangan berlangsung.

Pembelajaran akan optimal dan bermakna salah satunya dapat dicapai apabila guru kreatif dan inovatif dan selalu berusaha secara terus menerus untuk meningkatkan mutu proses belajar mengajar di kelas. Peningkatan mutu pembelajaran di kelas juga akan berpengaruh pada mutu pendidikan pada umumnya. Upaya memperbaiki dan meningkatkan mutu pendidikan di kelas harus dilakukan. Salah satu upaya tersebut yaitu dengan melakukan penelitian tindakan kelas (PTK) (Fayanto, 2018). Penelitian Tindakan Kelas (PTK) atau Classroom Action Research merupakan suatu model penelitian yang dikembangkan di kelas atau suatu bentuk kajian yang bersifat reflektif oleh pelaku tindakan, untuk meningkatkan kemantapan rasional dari tindakan-tindakan mereka dalam melaksankan tugas, memperdalam pemahaman terhadap tindakantindakan yang dilakukan, serta memperbaiki dimana praktik-praktik pembelajaran dilaksanakan. Melalui tindakan kelas kekurangan atau kelemahan yang terjadi dalam proses belajar mengajar dapat teridentifikasi dan terdeteksi untuk selanjutnya dicari solusi yang tepat (Kunlasomboon et al.2015; Narmaditya et al. 2017) .

Berdasarkan hasil observasi di SMAN 1 Piyungan, Bantul khusus kelas $\mathrm{X}$ MIPA menunjukkan bahwa proses pembelajaran yang dilaksanakan masih bersifat konvensional. Hal ini dikarenakan minat baca siswa rendah baik buku pelajaran atau sumber belajar lain yang menunjang proses belajar mengajar dikelas. Guru lebih aktif dalam proses pembelajaran di kelas sehingga siswa lebih banyak pasif, dengan demikian hasil belajar siswa masih kurang bahkan dibawah kriteria ketuntasan minimal. Kriteria Ketuntasan Minimal (KKM) SMAN 1 Piyungan rata-rata mencapai 75 . Rendahnya capain nilai fisika siswa dikarenakan siswa kurang mampu menyelesaikan permasalahan sesuai tahapan-tahapan penyelesaian soal serta minat belajar fisika siswa yang masih rendah.

Melihat pokok permasalahan yang ada , maka perlu adanya model pembelajaran yang 
tepat sesuai materi yang dipelajari agar hasil belajar siswa meningkat. Model pembelajaran yang dapat digunakan adalah menggunakan model discovery learning. Pembelajaran model discovery learningyang berawal dari pemberian stimulan yang berupa bacaan, gambar atau situasi sesuai dengan materi yang dipelajari diharapkan siswa lebih tertarik dan aktif dalam pengalaman mengamati suatu pokok permasalahan yang dihadapi serta dikaitkan dengan permasalahan dalam kehidupan seharihari sangat cocok diterapkan di SMAN 1 Piyungan khususnya klas X MIPA. Model pembelajaran dicovery learning merupakan model pembelajaran yang berdasarkan pengalaman langsung dan pentingnya pemahaman struktur atau ide-ide penting terhadap suatu disiplin ilmu yang melibatkan siswa secara aktif dalam pembelajaran sehingga pemahaman dan hasil belajar fisika siswa meningkat. Bahan ajar yang diberikan berupa permasalahan atau pertanyaan yang harus diselesaikan siswa dengan demikian siswa memperoleh pengetahuan dengan penemuannya sendiri tidak melalui pemberitahuan. Menurut Bruner (1996) menyatakan bahwa proses belajar akan berjalan dengan baik dan kreatif apabila guru memberi kesempatan pada siswa untuk menemukan suatu konsep, teori, aturan atau pemahaman melalui contoh-contoh yang dijumpai dalam kehidupannya. Penggunaan discovery learningdimaksudkan untuk mengubah pola belajar siswa yang pasif menjadi aktif dan kreatif.

Berdasarkan uraian yang telah diuraikan, penerapan pembelajaran model discovery learningdiyakini dapat meningkatkan keaktifan belajar dan hasil belajar siswa. Penerapan pembelajaran dengan discovery learningsangat cocok diterapkan di kelas X MIPA SMAN 1 Piyungan. Oleh karena itu akan dilakukan penelitian tindakan kelas yang berjudul Upaya Meningkatkan Keaktifan Belajar dan Hasil Belajar Fisika Siswa Kelas X MIPA dengan Model Discovery learning SMAN 1 Piyungan Semester Gasal Tahun Pelajaran 2019/2020.

\section{METODE}

Penelitian ini termaksud dalam Penelitian Tindakan Kelas (PTK). Penelitian dilaksanakan selama 4 bulan yaitu bulan mulai bulan Juli sampai dengan bulan Oktober 2019. Penelitian dilaksanakan di SMA N 1 Piyungan, Bantul yaitu siswa kelas X MIPA 2 semester gasal tahun pelajaran 2019/2020. Pengambilan siswa kelas X MIPA 2 berdasarkan pengamatan dan hasil belajar siswa masih kurang baik, banyak siswa yang harus remidi untuk mencapai nilai kriteria ketuntasan minimal (KKM). Peneliti mengajar pada siswa kelas X MIPA2 setiap hari Senin selama 1 jam pelajaran dan hari Rabu selama 2 jam pelajaran

\section{Subjek dan Objek Penelitian}

Subyek penelitian ini adalah siswa kelas $\mathrm{X}$ MIPA2 SMA N 1 Piyungan sejumlah 36 siswa terdiri dari 16 siswa laki-laki dan20 siswa perempuan. Obyek penelitian adalah aktivitas dan hasil belajar siswa dengan model DL untuk materi besaran fisis.

\section{Teknik Pengumpulan Data dan Analisis Data}

Dalam pengumpulan data pada penelitian ini menggunakan 3 macam teknik. Adapun teknik yang digunakan dalam penelitian tindakan kelas (PTK) adalah metode observasi,metode angket dan tes. Sedangkan analisis data mengunakan analisis deskriptif dengan berdasarkan pada kriteria keberhasilan aktivitas belajar siswa, kriteria keberhasilan pembelajaran guru dan kriteria keberhasilan belajar siswa.

\section{Indikator Keberhasilan}

Indikator keberhasilan dalam penelitian tindakan kelas ini adalah :

1. Terdapat peningkatan aktivitas belajar siswa ditandai dengan aktivitas siswa untuk bertanya, menjawab pertanyaan, menyelesaikan tugas tepat waktu sesuai materi pengukuran besaran fisis dengan model pembelajaran discovery learning (DL)

2. Terdapat peningkatan keberhasilan belajar siswa kelas X MIPA SMA Negeri 1 Piyungan tahun pelajaran 2019/2020 pada materi pengukuran besaran fisis ditandai dengan rata-rata nilai 65 sesuai KKM secara 


\section{Jurnal Penelitian Pendidikan Fisika, Vol. 5 No. 1 Januari 2020, 1-8 \\ Available Online at http://ojs.uho.ac.id/index.php/JIPFI \\ p-ISSN: 2502-3861 | e-ISSN: 2715-551X}

individu dan ketuntasan klasikal mencapai $85 \%$.

\section{Prosedur Penelitian}

Prosedur penelitian menggunakan dua siklus yaitu siklus 1 dan siklus 2. Masing masing siklus terdiri dari (1) Planning ( perencanaan ), (2) Action (tindakan), (3) Observasi (pengamatan ), (4) Reflection (refleksi).

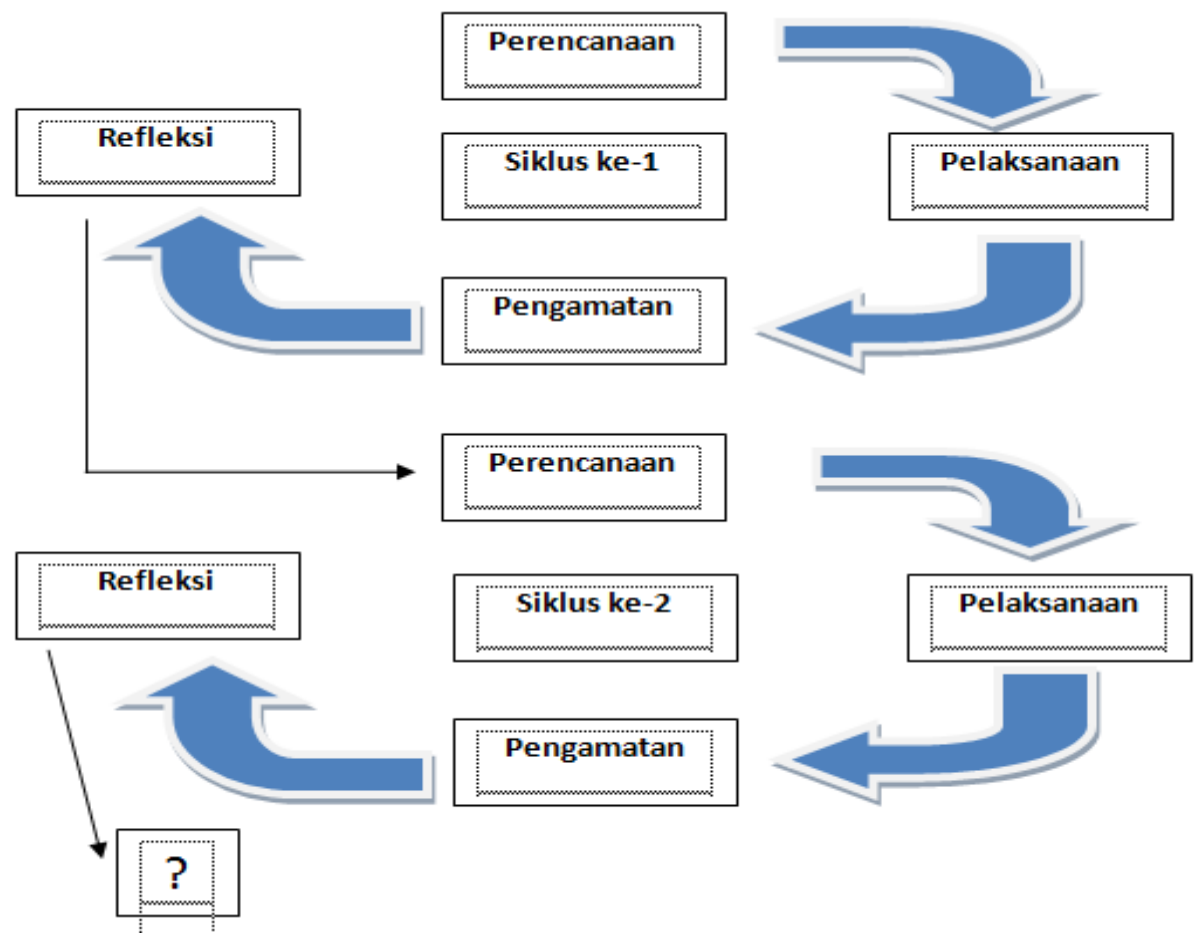

Gambar 1. Siklus penelitian tindakan kelas pada proses pembelajaran

Tahap-tahap penelitian tindakan kelas :

\section{Siklus I}

a. Perencanaan (Planning )

(1) Membuat Rencana Pelaksanaan

Pembelajaran (RPP). Rencana pelaksanaan pembelajaran dijabarkan dari silabus tentang pengukuranbesaranfisis. RPP yang dibuat disesuaikan dan menerapkan model Discovery learningagar pembelajaran yang berlangsung secara aktif dan menyenangkan, dan kemandirian sesuai dengan bakat, minat dan perkembangan fisik serta psikologis peserta didik.

Menyiapkan Lembar Kerja Siswa untuk diskusi kelompok, (3) Menyusun dan menyiapkan lembar observasi serta skala sikap, (4) Membuat kisi-kisi soal dan menentukan indikator keberhasilan, (5) Menyiapkan soal pretes dan posttes, (6) Menyiapkan soal ulangan .

b. Pelaksanaan tindakan (Acting)
Tahap kedua dari penelitian tindakan kelas adalah pelaksanaan tindakan, tahapan yang berlangsung ini merupakan realisasi dari segala teori pendidikan dan teknik mengajar yang sudah dipersiapkan sebelumnya. Langkah- langkah yang dilakukan oleh pendidikan tentu saja mengacu pada kurikulum yang berlaku dan digunakan sesuai kurikulum yang berlaku dan digunakan ditempat penelitian, serta hasilnya diharapkan berupa peningkatan keaktifan proses pembelajaran yang bertujuan untuk peningkatan hasil belajar siswa.

Tindakan yang digunakan dalam penelitian adalah menggunakan model Discovery learning (DL) yang disesuaikan dengan rencana tindakan yang telah disusun dan disiapkan sebelumnya.

Tindakan dalam penelitian ini dibagi menjadi 2 siklus, agar hasil penelitian sesuai dengan yang diharapkan. Beberapa yang akan dilakukan dalam 
hal ini, sebagai berikut : (1) Mengucapkan salam pada peserta didik. (2) Guru mengecek kehadiran siswa. (3) Guru mengadakan pretes tentang materi pengukuran besaran fisis. (4) Guru membimbing siswa dalam membentuk kelompok (5) Siswa membaca literasi dari buku tentang materi pengukuran besaran fisis, (6) Guru menyampaikan tugas pertanyaan tentang pengukuran besaran fisis dalam bentuk LKS, (7) Peserta didik secara berkelompok menyelesaikan tugas yang diberikan guru (8) Masing-masing kelompok mempresentasikan hasil kerja kelompoknya. (9) Guru memberi kesempatan pada kelompok lain untuk menanggapi hasil kerja kelompok, (10) Guru memberikan jawaban dari tugas yang diberikan pada siswa, (11) Guru bersama-sama siswa membuat kesimpulan dari hasil diskusi, (12) Guru mengadakan posttes, (13) Guru memberi tes akhir pada siklus I untuk mengetahui hasil belajar siswa.

c. Pengamatan (Observing)

Guru atau kolaborator mengamati aktivitas guru dan siswa dalam pembelajaran, kemudian dilakukan refleksi agar ada perbaikan dan peningkatan pada pembelajaran selanjutnya. Pengamatan yang dilakukan untuk mengetahui sejauh mana siswa mengetahui dan memahamni apa yang telah disampaikan saat pembelajaran. Pengamatan yang dilakukan yaitu terhadap siswa dan guru oleh observer.

1) Pengamatan aktivitas guru dalam pembelajaran

a. Kegiatan awal: (1) Memberi salam pembuka dan memimpin doa, (2) Memberi apersepsi dan tanya jawab tentang pentingnya mempelajari materi pengukuran besaran fisis, (3) Menjelaskan tujuan pembelajaran yang akan dilakukan serta model pembelajaran yang akan dilaksanakan.

b. Kegiatan inti: (1) Penguasaan materi, (2) Menguasai seluruh materi yang akan dipelajari, (3) Mengakitkan materi dengan masalah nyata, (4) Pendekatan strategi pembelajaran, (5) Melaksanakan pembelajaran sesuai dengan tujuan pembelajaran yang hendak dicapai, (6) Melaksanakan pembelajaran sesuai model discovery learning, (7) Melaksanakan penguasaan kelas dengan baik,

Melaksanakan sesuai alokasi waktu.

c. Kegiatan penutup: (1) Membuat rangkuman materi, (2) Mengadakan umpan balik, (3) Penilaaian proses pembelajaran, (4) Memimpin doa dan memberi salam penutup.

2) Pengamatan peserta didik/siswa dalam pembelajaran: (a) Mendengarkan penjelasan guru dan aktif bertanya, (b) Membaca literasi/bahan ajar, (c) Merumuskan masalah, mengumpulkan data dan mengolah data, (d) Melakukan diskusi kelompok secara aktif dan kerjasama, (e) Menjawab pertanyaan atau permasalahan dari guru secara aktif, (f) Aktif mengerjakan LKS sesuai petunjuk guru, (g) Berani menyampaikan pendapat untuk pemecahan masalah, (h) Berani mempresentasikan hasil diskusi, (i) Bekerja penuh tanggung jawab dan tepat waktu, (j) Membuat rangkuman atau kesimpulan diskusi didepan kelas.

d) Refleksi Tindakan (Reflecting)

Pada tahap ini kegiatan yang dilakukan adalah merefleksikan kegiatan yang telah dilakukan siswa selama pelaksanaan pembelajaran, apakah siswa berperan aktif dalam pembelajaran, apakah siswa mampu memahami materi yang dipelajari, apakah ada peningkatan aktivitas belajar, apakah ada peningkatan hasil belajar setelah menggunakan Discovery learning. Hal ini dimaksudkan sebagai refleksi bagi guru atau siswa pada siklus berikutnya.

\section{Siklus 2}

Penerapan siklus 2 untuk mengidentifikasi kekurangan dan kelemahan yang ada pada siklus 1. Proses siklu 2 sama halnya seperti yang ada pada Siklus 1.

\section{HASIL DAN PEMBAHASAN Deskeprisi Kondisi Awal}

Penelitian tindakan yang akan dilakukan pada siswa kelas X MIPA 2 di SMA Negeri 1 Piyungan melihat kenyataan bahwa hasil belajar fisika siswa masih rendah. Pada kenyataan yang terjadi bahwa siswa kurang aktif saat pembelajaran. Demikian pula masih banyak ditemukan siswa yang malu-malu bertanya apabila ada materi yang kurang jelas dan siswa 


\section{Jurnal Penelitian Pendidikan Fisika, Vol. 5 No. 1 Januari 2020, 1-8}

Available Online at http://ojs.uho.ac.id/index.php/JIPFI

p-ISSN: 2502-3861 | e-ISSN: 2715-551X

masih belum percaya diri untuk menyampaikan pendapat atau jawaban atas pertanyaan dari guru. Pada saat pembelajaran juga masih ada siswa yang ramai dengan teman sebangku, ada pula yang asyik bermain HP. Apabila ada tugas yang harus diselesaikan siswa kurang memberi respon positif dengan menunda pengumpulan tugas yang seharusnya dikumpulkan. Pembelajaran masih bersifat konvensional, sehingga banyak siswa yang mengantuk dan kurang berminat pada saat pembelajaran fisika. Hasil ulangan juga menunjukkan banyak siswa yang belum tuntas dari 36 siswa, hanya 10 anak yang nilainya di atas KKM yaitu $27 \%$.

Berdasarkan kenyataan yang telah diuraikan maka dilaksanakan penelitian tindakan kelas pada siswa kelas X MIPA 2 SMA N 1 Piyungan dengan pembelajaran menggunakan model discovery learning $(D L)$ pada materi pengukuran besaran fisis. Pembelajaran dengan DL diharapkan dapat meningkatkan minat dan hasil belajar fisika siswa. Pembelajaran dengan model Discovery learning akan membuat suasana belajar siswa yang efektif dan kondusif dan siswa dapat berlatih memecahkan masalah dan menggali pengetahuan fisika seara mandiri dalam kehidupan sehari-hari sesuai dengan materi yang sedang dipelajari.

\section{Keaktifan dan minat siswa dalam mengikuti pembelajaran dengan Discovery learning (DL)}

Pengamatan keaktifan siswa selama mengikuti pembelajaran dengan Discovery learning dilakukan oleh kolaborataor menunjukkan adanya peningkatan dari siklus I ke siklus II. Hal ini menunjukkan bahwa siswa pada saat pembelajaran siklus I masih kurang aktif terutama saat diskusi yang awalnya anak masih malu-malu bertanya dan mengemukan pendapat. Hasil pengamatan aktivitas siswa pada masing masing siklus adalah sebagai berikut :

Tabel 1. Perbandingan prosentase aktivitas siswa saat pembelajaran

\begin{tabular}{ccccc}
\hline \multirow{2}{*}{ Siklus } & \multicolumn{2}{c}{ Pertemuan I } & \multicolumn{2}{c}{ Pertemuan II } \\
\cline { 2 - 5 } & Kategori & Prosentase & Kategori & Prosentase \\
\hline Siklus I & Sangat Aktif & $88,5 \%$ & Sangat aktif & $93,0 \%$ \\
Siklus II & Sangat Aktif & $92,1 \%$ & Sangat aktif & $97,0 \%$ \\
\hline
\end{tabular}

Dari tabel 1 dapat dibandingkan aktivitas siswa dari pertemuan I pada siklus I dari $88,5 \%$ naik menjadi $93 \%$ pada pertemuan kedua. Pada siklus II pertemuan pertama aktivitas siswa juga naik dari $92,1 \%$ dengan kategori aktif menjadi kategori sangat aktif dengan prosentase $97,0 \%$. Jadi dapat disimpulkan bahwa ada peningkatan aktivitas siswa dalam pembelajaran dengan discovery learning dari siklus I ke siklus II, siswa sudah mulai suka dan tertarik dengan model pembelajaran. Rasa senang dan suka terhadap pembelajaran dengan discovery learning ditunjukkan dengan peningkatan aktivitas belajar siswa saat pembelajaran.

\section{Pelaksanaan pembelajaran DL oleh guru}

Berdasarkan pelaksaan pembelajaran yang dilakukan oleh guru pada siklus I ke siklus II ada kenaikan aspek-aspek yang dilakukan oleh guru. Hal ini setelah pembelajaran pada silkus I guru diberi masukan oleh kolaborator untuk peningkatan pembelajaran selanjutnya yaitu pada siklus II. Masukan tersebut tentunya sebagai patokan untuk perbaikan kegiatan guru dalam pembelajaran selanjutnya. Prosentase kenaikan aspek-aspek kegiatan guru disajikan pada Tabel 2.

Tabel 2. Perbandingan prosentase kegiatan guru pada setiap siklus

\begin{tabular}{ccc}
\hline Siklus & Kategori & Prosentase \\
I & Cukup aktif & $66,3 \%$ \\
II & Aktif & $78,8 \%$ \\
\hline
\end{tabular}

Dari Tabel 2 menunjukan adanya peningkatan dan perbaikan kegiatan guru dalam pelaksanaan pembelajaran dari prosentase $66,3 \%$ pada siklus I menjadi $78,8 \%$ pada siklus II. Hal ini berarti kekurangan aspek pada siklus I sudah diperbaiki guru pada siklus II sehingga menunjukkan adanya perubahan perbaikan dalam pembelajaran. Tampak bahwa aktivitas 
pembelajaran yang dilakukan guru pada siklus II sudah baik dalam hal pengelolaan pembelajaran di kelas,yaitu guru menyampaikan tujuan pembelajaran dan indikator pencapain dengan model discovery lerning, guru menanggapi dan menjawab pertanyaan yang disampaikan, guru membimbing siswa dalam mengumpulkan data dan menolag data, guru menarik kesimpulandari materi yang diajarkan serta mengelola waktu dengan baik. Hal ini sesuai dengan pendapat dari Sani (2014) yaitu langkah langkah pembelajaran dengan model discovery learning yaitu memberi rangsangan/stimulus, identifikasi masalah, pengumpulan data, mengolah data, pembuktian serta menarik kesimpulan.

\section{Hasil belajar siswa}

Hasil belajar siswa dilihat dari hasil ulangan pada siklus I dan siklus II. Ulangan dilaksanakan setiap akhir setiap siklus hal ini untuk melihat adanya peningkatan atau tidak dari hasil belajar fisika siswa pada materi besaran dan satuan . Perbandingan hasil belajar pada siklus I dan siklus II ditampilan pada Tabel 3.

Tabel 3. Hasil belajar fisika siswa

\begin{tabular}{llccc}
\hline No & Aspek-aspek & Hasil siklus I & Hasi klus II & Peningkatan \\
\hline 1 & Jumlah siswa & 36 & 36 & - \\
2 & Nilai rata-rata & 70,17 & 75 & 4,83 \\
3 & Nilai $\geq 75$ & 22 & 28 & 6 \\
4 & Nilai $<75$ & 14 & 6 & 9 \\
5 & $\%$ keberhasilan & $61 \%$ & $77,8 \%$ & \\
6 & Kriteria & Berhasil & Berhasil & \\
\hline
\end{tabular}

Berdasarkan hasil nilai belajar fisika siswa (Tabel 3) dari siklus I siswa yang tuntas sebanyak $61 \%$ atau ada 22 siswa yang tuntas mencapai nilai KKM. Sedangkan pada siklus II terdapat 28 anak yang tuntas yaitu $77,8 \%$, berarti hasil belajar siswa dari siklus I ke siklus II ada peningkatan 16,8 \%. Hal ini menunjukkan bahwa hasil belajar fisika siswa dengan pembelajaran discovery learning dapat meningkat. Peningkatan ini karena siswa sudah mulai paham akan materi yang sedang dipelajari, karena sudah tetarik dan berminat untuk belajar dengan model pembelajaran discovery learning. Hal ini sesuai dengan teori yang menyatakan bahwa hasil belajar merupakan suatu proses usaha yang telah dicapai seseorang untuk mendapatkan sebuah perubahan tingkah laku yang baru secara keseluruhan sebagai suatu pengalaman terhadap lingkunganya (Slameto, 2010).

\section{Hasil respon siswa terhadap pembelajaran dengan model Discovery Learning}

Respon siswa terhadap pembelajaran dengan discovery learning berdasarkan angket yang disebarkan dilaksanakan pada akhir tiaptiap siklus setelah ulangan. Berdasarkan responden siswa pada siklus I diperoleh prosentase sebesar $55,9 \%$ sedangkan pada siklus II diperoleh $80,1 \%$ yang menyatakan setuju atau senang terhadap pembelajaran fisika dengan discovery learning. Dengan demikian ada peningkatan respon siswa sebesar $24,2 \%$. Siswa mempunyai respon positif terhadap pembelajaran dengan discovery learning (DL).

Berdasarkan pengamatan bahwa model pembelajaran discovery learning (DL) pada materi pengukuran besaran fisis dapat meningkatkan aktivitas belajar fisika siswa , siswa lebih mudah dalam memahami materi pelajaran serta dapat meningkatkan hasil belajar fisika siswa kelas X MIPA 2 SMA Negeri 1 Piyungan.

\section{KESIMPULAN}

Dari hasil penelitian dan pembahasan yang telah diuraikan diatas dapat ditarik kesimpulan sebagai berikut :

1. Model pembelajaran dengan discovery learning (DL) dapat meningkatkan aktivitas belajar fisika siswa kelas X MIPA2 SMA Negeri 1 Piyungan, Bantul pada materi pengukuran besaran fisis tahun pelajaran 2019/2020. Peningkatan aktivitas belajar fisika siswa kelas X MIPA SMA1 Negeri 1 Piyungan dengan discovery learning (DL) 
pada pengukuran besaran fisis tahun pelajaran 2019/2020 dari siklus I pada pertemuan pertama dan pertemuan kedua mengalami peningkatan dari $88,5 \%$ menjadi $93,0 \%$ yaitu $4,50 \%$. Pada siklus II mengalami peningkatan dari $92,1 \%$ menjadi $97,0 \%$ ada peningkatan $4,90 \%$.

2. Model pembelajaran dengan discovery learning (DL) dapat meningkatkan hasil belajar fisika siswa kelas X MIPA 2 SMA Negeri 1 Piyungan, Bantul pada materi pengukuran besaran fisis tahun pelajaran 2019/2020.Peningkatan hasil belajar fisika siswa kelas $\mathrm{X}$ MIPA SMA Negeri 1 Piyungan dengan discovery learning (DL) pada materi pengukuran besaran fisis tahun pelajaran 2019/2020 pada siklus I ke siklus IIdari $61 \%$ menjadi $77,8 \%$ mengalami kenaikan $16,8 \%$. Adanya peningkatan hasil belajar menunjukkan bahwa discovery learning yang dilaksanakan dapat menyenangkan dan membuat siswa berminat dan tertarik dalam pembelajaran tersebut.

\section{DAFTAR PUSTAKA}

Bruner, J. S. (1996). The culture of education. UK: Harvard University Press.

Kawuri, M. Y. R. T., Ishafit, I., \& Fayanto, S. (2019). Efforts to improve the learning activity and learning outcomes of physics students with using a problem-based learning model. IJIS Edu: Indonesian Journal of Integrated Science Education, 1(2).

Kunlasomboon, N., Wongwanich, S., \& Suwanmonkha, S. (2015). Research and development of classroom action research process to enhance school learning. Procedia-Social and Behavioral Sciences, 171, 1315-1324.

Kurniasih, S. (2014). Strategi - strategi pembelajaran. Bandung: Alfabeta.

Narmaditya, B. S., Winarning, W., \& Wulandari, D. (2017). Impact of problembased learning on student achievement in economics course. Classroom Action Research Journal (CARJO), 1(1), 1-11.
Sanjaya, W. (2006). Pembelajaran dalam implementasi kurikulum berbasis kompetensi. Jakarta: Perdana Media.

Sofyan, H., \& Komariah, K. (2016). Pembelajaran problem based learning dalam implementasi kurikulum 2013 Di SMK. Jurnal Pendidikan Vokasi, 6(3), 260271.

Slameto. (2010). Belajar dan faktor-Faktor yang Mempengaruhinya. Jakarta: Rineka Cipta.

Sukariasih, L., Ato, A. S., Fayanto, S., Nursalam, L. O., \& Sahara, L. (2019, October). Application of SSCS model (Search, Solve, Create and Share) for improving learning outcomes: the subject of optic geometric. In Journal of Physics: Conference Series (Vol. 1321, No. 3, p. 032075). IOP Publishing.

Fayanto, S., Misrawati, M., Sulisworo, D., Istiqomah, H. F. N., \& Sukariasih, L. (2019). The implementation of multimedia on physics learning based on direct instruction model in the topic of light. Indonesian Journal of Learning Education and Counseling, 1(2), 124-132.

Fayanto, S., Musria, M., Erniwati, E., Sukariasih, L., \& Hunaidah, H. (2019). Implementation of quantum teaching model on improving physics learning outcomes in the cognitive domain at junior high school. IJIS Edu: Indonesian Journal of Integrated Science Education, 1(2).

Trianto, M. P. (2010). Model pembelajaran terpadu: Konsep, strategi, dan implementasinya dalam Kurikulum Tingkat Satuan Pendidikan (KTSP). Kuala Lumpur: Kemetrian Pengajaran Malaysia. 